University of Louisiana at Monroe

From the SelectedWorks of Krishna Bista

2012

Silence in teaching and learning: Perspectives of a Nepalese graduate student

Krishna Bista 
This article was downloaded by: [Arkansas State University]

On: 04 April 2012, At: 13:21

Publisher: Routledge

Informa Ltd Registered in England and Wales Registered Number: 1072954 Registered office: Mortimer House, 37-41 Mortimer Street, London W1T 3J H, UK

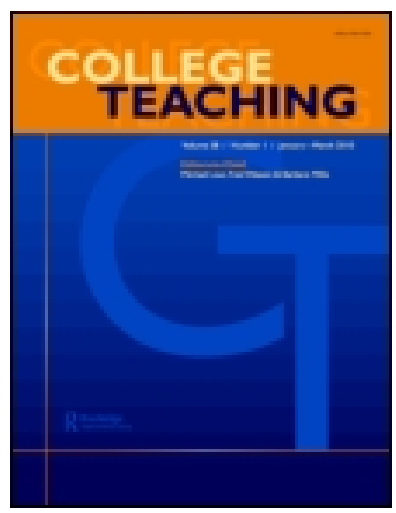

\section{College Teaching}

Publication details, including instructions for authors and subscription information:

http:// www. tandfonline.com/loi/vcol20

\section{Silence in Teaching and Learning: Perspectives of a Nepalese Graduate Student}

Krishna Bista ${ }^{a}$

${ }^{a}$ Arkansas State University

Available online: 04 Apr 2012

To cite this article: Krishna Bista (2012): Silence in Teaching and Learning: Perspectives of a Nepalese Graduate Student, College Teaching, 60:2, 76-82

To link to this article: http:// dx.doi.org/ 10.1080/87567555.2011.633943

PLEASE SCROLL DOWN FOR ARTICLE

Full terms and conditions of use: http://www.tandfonline.com/page/terms-and-conditions

This article may be used for research, teaching, and private study purposes. Any substantial or systematic reproduction, redistribution, reselling, loan, sub-licensing, systematic supply, or distribution in any form to anyone is expressly forbidden.

The publisher does not give any warranty express or implied or make any representation that the contents will be complete or accurate or up to date. The accuracy of any instructions, formulae, and drug doses should be independently verified with primary sources. The publisher shall not be liable for any loss, actions, claims, proceedings, demand, or costs or damages whatsoever or howsoever caused arising directly or indirectly in connection with or arising out of the use of this material. 


\title{
Silence in Teaching and Learning: Perspectives of a Nepalese Graduate Student
}

\author{
Krishna Bista \\ Arkansas State University
}

\begin{abstract}
The nature of silence is complex in any classroom with international or domestic students. Instructors sometimes fail to recognize that the classroom silence of foreign students is unlike their native counterparts. With an insider perspective, this article explores the concept of silence among international students by examining the existing body of literature relating to cultural norms. It also suggests a number of ways of dealing with silent students in a diverse classroom setting.
\end{abstract}

Those who know do not speak. Those who speak do not know.

$$
\text { -Lao Tzu }
$$

Recently, in a class discussion, the professor let the students speak on the issue of silence. Participants in the class shared the patterns of silence in teaching and learning and the roles of instructors in understanding the meanings of silence in a diverse class with students from diverse backgrounds (languages, cultures, religions, and nationalities). It gave me an opportunity to share my first experience in the U.S. classroom. Many students in that class were high school and college teachers. They shared their experiences and perceptions of silent students - both native and non-native speakers of English-in the classroom. Some of those teachers cum students were not familiar with the culture of silence in foreign countries. In general, the class highlighted the value of understanding silence for students whether they are native or foreign. Personally, this class reminded me of my own experience of understanding the U.S. classroom experience a few years ago.

For a couple of months during my first semester, I did not participate in class discussion. I hesitated to speak when it was my turn, and I performed very poorly in class participation. It was the first time that I noticed differences between an American classroom and a Nepalese classroom. When the teacher or classmates expected my point of view on issues related to Nepal or Asia, I became nervous-my face flushed

Correspondence should be sent to Krishna Bista, Arkansas State University, Center for Excellence in Education, P.O. Box: 1270 State University, ASU-Jonesboro, AR 72467-1270, USA. E-mail: Krishna.Bista@ smail.astate.edu very red, and my ears would get hot before I uttered any words. Many times I missed chances at discussion, although I felt I could have contributed, but being nervous simply made me too uncomfortable to speak. I used to have several ongoing internal monologues - as if I was in a movie scene in which the character went through a self-questioning and self-answering process. I made a list of the students who spoke and of those who did not in order to be happy with my silence. It made me happy if other students remained silent because I would not be the only person. However, it did not mean that I was ignoring the class or not paying attention or that I did not like to share my views. I was afraid that if I spoke in the class, my classmates would have problems with my accent. I felt that my words would not produce enough sound, and the message would not be understood. During class PowerPoint presentations, I was so nervous that I had to read lines without my personal explanation. I felt bad because I had the feeling that I was being left out of the class even though I actively listened and turned in all assignments.

Today, silence is widely used in various sectors of human life. The Google search engine found 140,000,000 words on silence in 0.10 of a second. According to this search, silence has been used in various genres such as music, public debate, law, spirituality, and so on as part of gestures and symbols. However, there are limited studies on silence in the existing body of literature concerning teaching and learning among domestic and international students in the American schools and colleges.

In this article, I will focus on the notion of silence among international students through students' perceptions and 
findings from the body of literature on silence. With my personal experiences in a narrative voice, this article will explore the reasons why foreign students are motivated to participate or remain silent in the classroom. The structure of this article includes silence in classroom scenarios, review of literature on silence, research findings on the culture of silence, and implications of silence for educators of international students and their counterparts, domestic students, in higher education.

\section{What is Silence in the Classroom?}

Tannen (1985) entitled her article on silence "Silence: Anything but" indicating that silence is anything but nothing: void. According to the Oxford Advanced Learner's English Dictionary, the term silence denotes "abstinence from speech or noise" (1255). "Silence" is different from "quiet" when it is taken for the purpose of classroom scenarios. "Quiet" refers to an objective state possessing no or slight sound or motion. Both terms can be used interchangeably in the educational setting. Silence forms when a gap occurs between a teacher's expectation of a response and the time that the respondent takes to respond. In such settings, it is not necessarily quiet in the classroom, but attention is drawn to this gap (Forrest 2010). In an inquiry process, the situation is not literally free of sound when the teacher's question is met with silence. For Forrest, the question leads to a response even in the silence. The sound beyond the space of the classroom forms some kind of response. According to Korzybski (quoted in Forrest 2010, 6), silence is created through the conflict between reality and expectations: "In reality, what is expected is absent and everyone is left waiting in what we perceive as silence." Paradoxically, silence would be deafening when several interior monologues take place as everyone waits for a voice to respond to the teacher's question. For Korzybski, the silence of this pause is "pregnant," i.e., full of potential consequences.

There is a debate regarding the value of silence in classrooms. Silent behavior was perceived as a barrier in learning (Bista 2011; Plakans 2011; Sivan et al. 2000). Clair (1998) agreed that "silence ... is perceived as a passive background to the noisy activity of communication" (p. 8). She explained that being silent is negative. Kalamaras (1994) asserted that "the West has misinterpreted the meaning of silence ... specifically the practice and awareness of silence-is misguided" (p. 4). He argued that Western conceptions of silence, as negative, are largely erroneous. As a result, teachers perceive silent students in American classrooms as passive learners.

For other scholars, silence is a rich communicative resource in understanding the subject matter (Jaworski and Sachdev 1998; Lickerman 2009; Armstrong 2007). They see silence as a power to motivate students' learning. As an outcome of his long teaching career, Forrest (2010) notices the value of silence "for its restorative powers" (10) in which students were encouraged to engage/speak. Picard (1948/1952), characterizing silence as a positive to itself, wrote:

Silence is not simply what happens when we stop talking. It is more than the mere negative renunciation of language; it is more than simply a condition that we can produce at will. When language ceases, silence begins. But it does not begin because language ceases. The absence of language simply makes the presence of silence more apparent. (P. xix)

Armstrong (2007) suggested that the culture of silence itself is a power to give voice to the marginalized students, and as a part of his three-year research studying cultures of learning at the University of Leeds, he found that silence was truly applicable to the classroom as well as to the wider community of speech. Some educators do not consider silence as a negative phenomenon of learning or the enemy of speech; but, for them, silence adds meaning to communicative interactions (Jaworski 1993; Picard 1952; Dauenhauer 1980). The role of silence in the metalinguistic function is a discourse marker (Ephratt 2008).

\section{Review of Literature: How Is Silence Discussed, Valued and Practiced?}

Silence in teaching and learning is largely evaluated in terms of class participation. Teachers encourage their students to participate orally in classroom discussions and they also assign daily participation grades (Howard and Henney 1998). The decision to speak in class discussion varies from student to student and even from class to class (Meyer 2007). The case of silence in the classroom varies in both the school and college settings.

Jaworski (2005) said silence in the institutional setting was neglected for several years. However, the majority of the studies on silence focus on English language teaching, basically among English as second language learners, exploring linguistic patterns and language proficiency. In a study, silence has been interpreted as guilt in criminal justice cases (Cotterill 2005). Besides, the notion of silence is ignored in the classroom of other disciplines such as the humanities, business, and social sciences. The existing body of literature does not mention the nature of silence in other fields such as social studies, history, psychology, etc. On a large scale, the papers published in a special issue of Multilingua-Journal of Cross-Cultural and Interlanguage Communication contributed to the field of silence in education. However, the study itself was limited to sociolinguistics.

Previous research on silence has focused on social and cultural phenomena of foreign students abroad. Zheng (2010) found that silent Chinese students identified themselves as the "cultural other" because of their low English proficiency and class participation as a negotiating process. Ping (2010) described her "in-class silence" experience while studying at London Metropolitan University. For her, the Confucian 
culture predominantly influenced her to be silent in her class discussion. Studies related to Chinese students have shown that their limited English language skills and ability to communicate among their peers and instructors was a major underlying cause of classroom silence (Jackson 2002; Liu and Littlewood 1997; Ping 2010). Educators focused on the Confucian cultural heritage, in which Chinese students were apparently passive and reticent in the classroom (Spizzica 1997). Students experienced teacher-centered instruction and placed a great degree of respect on their teachers for their wisdom and knowledge (Kirkbride and Tang 1999; Carson and Nelson 1996).

Some research has mentioned that Chinese students were intentionally silent in the classroom because they preferred less frequent participation and offered brief responses to avoid being labeled as a "show-off" to their Chinese peers (Liu and Littlewood 1997). Hu and Fell-Eisenkraft (2003) studied eight immigrant Chinese students' use of silence in the language arts classroom. They explained students' perceptions of silence as an insider and an outsider. As an insider, they dealt with social and cultural aspects of students, and as an outsider they found that instructors sometime misjudged the silent nature of their students. Zhou, Knoke, and Sakamoto (2005) argued that the silence among Chinese students was not limited to their cultural and linguistic differences. The reactions of their professors and peer students in the classroom influenced their level of subsequent participation.

Harumi (2010) studied the classroom silence of Japanese students studying English as a Foreign Language (EFL) in cross cultural settings in the UK for more than a decade as a part of her doctoral dissertation in the late 1990s. Through her ethnographic study, she discovered that at the roots of silence inside the Japanese classrooms were linguistic (limited vocabulary, expression, grammar, etc.), psychological (shyness, boredom, lack of confidence, etc.), and socio-cultural (Confucian ethics, classroom culture, etc.) factors. Harumi noticed a problem of time associated with silence because foreign students take a longer time in their thought processes. Nakane (2005) performed a case study of Japanese students in Australia, which concluded that silence was constructed in negotiation of participation in the classroom.

Tatar (2008) focused on the classroom participation behavior of four Turkish graduate students and found that silence was deeply related to socio-cultural and educational factors. She focused on the fact that international students come from teacher-centered educational cultures in which they do not speak without being called on. As a result, the rules and expectations of classroom participation in the U.S. for those students is unfamiliar and complex. In a study of Asian students' classroom communication patterns, Liu (2001) explored Asian students' cultural adaptation to academic life in the U.S. universities. This study included twenty Asian students and measured their learning patterns in terms of culture, language, and adaptation.
Karim and Shah (2008) examined the nature of silence among 250 students at the International Islam University in Malaysia in which the degree of classroom participation anxiety was higher with Malaysian students than with nonMalaysian students. Malley (2005) studied interactions and meanings of the silence of midwives in a clinic in Ireland and found that the subjective experience of pregnancy and labor were kept silent. Xing and Spencer-Oatey's (2005) study with two Chinese-British business meetings suggested that people's perceptions of silence depended on their expectations in intercultural interactions. Sometimes their cultural boundaries forced them to be silent.

Ollin (2008) observed 25 teacher participants and studied silent pedagogy and classroom practice. He identified different types of silences in classroom teaching and learning. Ollin believed that silence would be perceived negatively if teachers became culturally biased towards talk. Ollin (2008) found:

When learners were silent in terms of not talking they might be engaged in a variety of internal activity-listening, cognitively processing, emotionally processing, and emotionally withdrawing. When the teacher was silent it was suggested they could be listening to gauge whether learners had understood. If both learners and teachers were silent then this might represent productive and comfortable engagement with the work of the classroom. (272)

In short, there have been several studies, lacking in depth and carried out in the past two decades, about the nature of silence in classroom settings. Among those studies, I did not find any similarities on relevant findings among scholars and researchers in terms of age, gender, and nature of study. The majority of the studies were limited to the English language classroom learners. I did not find any comparative research work on silence among American students and other foreign students on a large scale. Studies among British students or Australian students were also limited. Judging from student perspectives, there is not any research to uncover the reasons why some students choose to remain silent even when participation in classroom discussion is encouraged or graded. Some areas for future research could be: what is the degree of silence in the classroom with native English students and non-native English learners? Or, how do teachers perceive silence in American classrooms in non-linguistics majors?

In the following sections, I will explore the nature of silence from my personal experience as an international student with American and non-American peers in the United States.

\section{A Self-Reported or Analyzed Silence in the Classroom}

In my first semester, I was nervous in class discussions although my level of written English and ability to understand it 
was fairly good. I perspired a lot and lost my train of thought while speaking. My English sounded awkward, and the class and the professor did not understand my accented English. I did not join class discussion out of fear that I would be unable to deal with the possible conflicts or misunderstandings. My self-esteem was low, and I felt a sense of incompetence being in a graduate class.

In my experience, language is a barrier for many nonnative English speaking students. Those who have a lower level of English proficiency face problems in class participation that naturally force them to be silent in class. Research findings suggest that learners fear that they will appear foolish by making mistakes such as simple errors in grammar or in pronunciation. These are the major issues that emerged from the studies carried out with Chinese, Japanese, Malaysian and Turkish students (Brick and Louie 1994; Harumi 2010; Tatar 2008; Nakane 2005; Zheng 2010).

\section{Lack of Understanding of Academic Culture and Knowledge in the United States}

On the mid-term exam in the first semester of a Young Adult Literature course, I wrote a four-page answer for each question in an hour. I was the only student writing beyond the assigned exam time because I did not know how much to write. I grew up with the concept that the longer the answer, the better the grade. The Nepalese classroom did not consist of class participation, presentations, term papers or quizzes like in American teaching and assessment. My teacher later explained to me how to write on U.S. exams and how to share my views with the class.

Growing up in chalk and duster classrooms, I mostly depended on teachers' lectures for course materials and preparation for the finals. The Nepalese classroom, especially in rural districts, did not have basic teaching aids such as computers, televisions or Xerox machines. Class attendance or course assignments were not the norms in the university system. Coming from that background to the American classroom, I was as lost as a crow in the mist. Unfortunately, I was not taught how to participate in the American classroom. In Nepal, students are expected to be quiet in the classroom. I was required to ask permission upon entering, and I was not allowed to answer a question without standing. I did not know that being silent was a problem in American classrooms. Gradually, I recognized the rules and expectations. Until that time, I was the odd ball in the classrooms for several months!

As an international student, I realized that we are unfamiliar with American academic culture. The existing literature also shows that silence is a common trend for most foreign students in a new classroom culture. Chinese, Japanese, Indian, Malaysian and other Oriental students are highly influenced by home cultures and traditions. They grew up being loyal and respectful to elders, teachers, and relatives. They were taught to be silent in the classroom. A deep level of social and cultural stigma is connected with these students' need to be silent.

\section{Indigenous Knowledge Sharing/ Fear of Cultural Mistakes}

What cultural values, norms, and identities do I bring to the classroom? I felt awkward and ashamed to share my ethnic background. Cultural dignity such as a poor social and cultural background mattered to me and was sometimes a barrier for me to speak up about what I knew. One of my friends said, "After watching the movie, The Slumdog Millionaire (2008), I found India is a very dirty and poor country. Actually, I had expected it better." I felt sad hearing that I was from a dirty country even though I was not from India. I was silent instead of sharing my experience. "I explored sad sides of the country in education, development and technology when I started knowing more about Nepal," said my teacher who ran a comparative education project in Nepal. Such anecdotes also discouraged me from sharing my views in class. As in my case, studies have shown that such social and cultural differences do not encourage foreign students to speak up in the class. For example, Chinese and Japanese students' ethnic and cultural knowledge contributed to silence in the classroom (Nakane 2005; Jaworski 2005).

When students like me come with a silent self to the classroom, they feel discomfort in speaking. They fear making mistakes or inappropriate responses in the class. They worry about their ethnic and cultural values that do not make any sense in another cultural setting. Basically, developing Asian countries still have so many traditional values that make it difficult for students to adapt to another culture.

\section{Strong Beliefs on Traditional Learning Style}

My teachers from the school and college were happy if their students were silent in the classroom. It was a classroom requirement that students listen to the lectures of their teacher. It was an easy way for teachers to manage a class with many students (sometimes sixty on average), if their students were silent. The mode of instruction was also teacher-centered. Teachers gave lectures no matter what grade they taught. Parents were also convinced that the more their children listened to the lectures, the better they would score on the finals. Therefore, in my context, I was forced/trained to be silent in class.

Like my situation, international students cannot isolate their home cultures and learning styles in the United States. Also, teacher-centered instruction is highly practiced in many Asian countries such as Bhutan, China, India, Japan, Nepal, Pakistan, and Sri Lanka. For Chinese students, the traditional learning style is connected to the Confucian concept of education. For students from India and Nepal, it is connected to the festival of learning, i.e., Saraswati Pooja. Because of such cultural backgrounds, Asian learners do not express 
themselves in American classrooms (Liu; 2001; Meyer 2009). In short, top-down communication, the gap between the teacher and the student, and teacher-centered classroom instruction are deeply rooted causes of silence for Asian students (Jaworski 2005; Nakane 2005; Tatar 2005, Wu 2009).

\section{Dynamics of Classroom Requirements}

I did not know at first that speaking in the American classroom means earning a grade. From primary schools to graduate programs in Nepal, none of the students' class participation was graded. Students were not required to present in the university classroom. There were not any attendance sheets for undergraduate and graduate students at Tribhuvan University, the oldest university in the country. During the first semester, it was hard for me to believe that my classroom speaking activities were graded. I noticed native students speaking on various topics in the classroom. Mostly they brought the issues of their homes, family members and work places into the classroom. For me, it was unacceptable to talk about such personal things in the classroom. Neither the teachers nor the students shared personal matters as a part of classroom participation in Nepal.

In the U.S. classroom, class participation was assumed to be an ethical obligation for both foreign and native students. The students who refused to actively participate in the class were acting unethically (Petress 2001). The instructor expected to hear students' responses, insights, observations or experiences on the subject matters orally. This classroom culture was a new phenomenon for me, and I believe for many foreign students as well, in my (their) first semester. It was surprising to me that speaking in the class meant participating —correct or incorrect comments were expected!

Many international students need to be encouraged to speak in the American classroom. To correct the mistaken perspective of silence, classroom participation should stimulate learning activities that both native and non-native students enjoy. To correct this false belief, Wood (1996) warned that "we must get away from the false assumption that the amount one learns is directly connected to the amount one does (or does not) talk" (111). For some international students, there could be pressure to participate in discussion as they may not be aware of this aspect of classroom participation or may face language or cultural anxiety about expressing their thoughts.

\section{Why are Foreign Students Silent in the U.S. Classroom?}

On the basis of my personal experience and previous research on silence, international students are silent because of the following reasons:

a. The culture of silence is deeply rooted within home cultures (e.g. Confucian ethics), values, expectations, and social norms. b. Asian students perceive silence as a classroom requirement because of the teacher-centered pedagogies in which the teachers expect them not to speak.

c. Learners perceive silence as the power to foster their ability to listen effectively and to have a clear view into the hearts of others.

d. Asian culture acknowledges silence as a form of "wisdom" and self-control or respect inside the classroom.

e. Students who are silent do not have enough linguistic proficiency to express their thoughts and opinions with clarity.

\section{Implications of Silence for Educators in Schools and Colleges}

The nature of silence is complex in any classroom with foreign or domestic students. There are a number of ways of dealing with silent students in multicultural classroom settings.

For instructors of international students, it is important to note cross-cultural perspectives in course readings and grading the classroom discussion. Because of lack of language proficiency or being unfamiliar with the American classroom culture, students from other countries feel stressed and frustrated. As seen in the existing body of literature, many Asian students do not know about learner-centered instruction. Even in my personal case, I was taught to be silent throughout school and college in listening to teachercentered instructions. To bridge this gap for international students, instructors could adopt strategies such as e-mailing study questions beforehand, giving clear directions, and asking specific questions or summarizing important points of the discussions (Tatar 2005). Brookfield (2006) suggested that teachers should research what students know, speak and experience as a part of understanding the classroom so that the lessons would be inclusive for both native and foreign students.

In a traditional classroom, a teacher speaks more than his or her students. Sometimes, instructors should be silent and observe how it affects students or should encourage speaking up. The balance of the class would be achieved when both domestic students and international students get an equal opportunity to share their thoughts and perspectives as a part of class discussion. A skillful teacher always allows enough time for her/his students to respond instead of expecting immediate responses to every question. Svinicki and McKeachie (2011) recommend a silence of 5 to 30 seconds for better outcomes in discussion. Instructors are expected to know the significance of cultural values and meanings in foreign cultures. Sometimes no eye contact or being silent does not necessary mean non-participation.

The U.S. students would benefit from the active participation of foreign students in the class. As they understand diverse social, cultural and linguistic experiences and perceptions of foreign students, the U.S. students should encourage 
and let foreign students speak in the class. Instead of leading classroom discussion with stories of their families, friends and work places, they should learn the world beyond those boundaries. They learn more from global and diverse views of international students if they encourage them.

Instead of being bound with home culture and educational experiences, international students also should look for ways to familiarize themselves with the host culture. Since their main goal of overseas study is to earn a foreign education, they should expose themselves to various social norms, cultures, and beliefs in the United States. They should speak up in class discussion because their voices and experiences are required as much as those of their American counterparts. Today the world is so diverse in terms of languages, cultures, religions, and socio-political affairs. Foreign students should adopt new cultures as a part of their learning journey.

\section{Conclusion}

The nature of silence is complex in any classroom with foreign or domestic students. However, the American classroom requires them to participate as this phenomenon is graded. For those international students who come from distinct social and cultural backgrounds, they always face a challenge when speaking in class. Instructors sometimes falsely assume that non-speaking students do not engage in learning. Some studies have reported that instructors incorrectly misinterpret students' silence as disengagement when using conventional understandings of silence but those silent students were engaging through other means such as paying attention, taking notes, or thinking about the material presented in class (Meyer 2009; Meyer and Hunt 2004). It appears, therefore, that a closer inspection of how international students engage in the classroom is essential. The relationship between silence and classroom expectations should be carefully examined. Consequently, nowhere is it more important to study silence than in a classroom context.

In a classroom environment, silence is often maintained by two parties: the students who remain silent and the instructor who does not ask questions to those silent students. In some cases, students may be reluctant to participate orally unless specifically invited to speak by the instructor. Fritschner (2000) found a general reluctance on the part of professors to directly question students, which reinforces the expectation of reticent students that the "talkers" can be relied on to answer questions or make comments. Not surprisingly, most student talk is with teachers and not with other students; however, required participation causes the student internal discomfort because students do not perceive a responsibility to participate (Aulls 2004). Classroom engagement is expected in cognitive (not always observable) and behavioral (observable) aspects.

Given that some students prefer to remain silent in various situations, while others are more willing to talk in class, it is reasonable to speculate that students have different preferences for participation in the classroom. As silence has multiple meanings in any teaching and learning classroom, teachers should not take the notion of silence literally. When students are silent, one cannot assume that they are not learning. For both international and domestic students, teachers should evaluate the classroom participation and the nature of silence with the knowledge of their ethnic, linguistic and cultural backgrounds. More attention should be paid to the classroom context in which such silence is manifested and to the classroom process through which such silence is produced.

\section{REFERENCES}

Armstrong, P. 2007, July. Cultures of silence: Giving voice to marginalized communities. Paper presented at the meeting of the Standing Conference on University Research and Teaching in the Education of Adults, Belfast, Northern Ireland.

Aulls, M. W. 2004. Students' experiences with good and poor university courses. Educational Research and Evaluation 10: 303-335.

Bista, K. 2011. Academic dishonesty among international students in higher education. In To improve the academy: Resources for faculty, instructional, and organizational development, ed. J. E. Miller \& J. E. Groccia, 30: 159-172.

Brick, J., \& G. Louie. 1994. Language and culture-Vietnam: Background notes for teachers in the adult migrant education program. Sydney: Adult Migrant Education Service.

Brookfield, S. 2006. The skillful Teacher: On techniques, trust, and responsiveness in the classroom. 2nd ed. San Francisco, CA: John Wiley and Sons, Inc.

Carson, J. G., \& G. L. Nelson. 1996. Chinese students' perceptions of ESL peer response group interaction. Journal of Second Language Writing 5: $1-19$.

Clair, R. N. 1998. The Social and Cultural Construction of Silence. The University of Rode Island. http://www.uri.edu/iaics/content/2003v12n3/ 08\%20Robert\%20N.\%20St.\%20Clair.pdf

Cotterill, J. 2005. 'You do not have to say anything ....' : Instructing the jury on the defendant's right to silence in the English criminal justice system. Multilingua 24: 7-24.

Dauenhauer, B. P. 1980. Silence: The phenomenon and its ontological significance. Bloomington, IN: Indiana University Press.

Ephratt, M. 2008. Functions of silence. Journal of Pragmatics 40: 19091938.

Forrest, M. 2010. Praising silence in a community of inquiry. Philosophy of Education Society of Great Britain Conference Paper. http://www. philosophy-of-education.org/uploads/papers2010/Forrest.pdf

Fritschner, L. M. 2001. Inside the undergraduate college classroom: Faculty and students differ on the meaning of student participation. The Journal of Higher Education 71: 342-362.

Harumi, S. 2010. Classroom silence: Voices from Japanese EFL learners. English Language Teaching Journal 65 (1): 1-10.

Howard, J. R., \& A. L. Henney. 1998. Student participation and instructor gender in the mixed-age college classroom. The Journal of Higher Education 69: 384-405.

Hu, Y., \& S. Fell-Eisenkraft. 2003. Immigrant Chinese students' use of silence in the language arts classroom: Perceptions, reflections, and actions. Teaching and Learning, 17(2): 55-65.

Jackson, J. 2002. Reticence in second language case discussion: Anxiety and aspiration. System 30: 65-84.

Jaworski, A. 1993. The power of silence: Social and pragmatic perspectives. Newbury Park, CA: Sage. 
Jaworski, A. 2005. Introduction: Silence in institutional and intercultural contexts. Multilingua, 24:1-6.

Jaworski, A., \& I. Sachdev. 1998. Beliefs about silence in the classroom. Language and Education 12(4): 273-290.

Kalamaras, G. 1994. Reclaiming the tacit dimension: Symbolic form in the rhetoric of silence. Albany, NY: State University of New York Press.

Karim, N. H., \& M. I. Shah. 2008. Silence is not golden: Investigating classroom participation anxiety among IIUM students. International Language Conference Proceedings, International Islamic University of Malaysia. www.iium.edu.my/ilc/?download $=31$-e08.pdf

Kirkbride, P. S., \& S. Tang. 1999. Chinese conflict preferences and negotiating behaviors: Cultural and educational experience and expectation of international postgraduate students in the UK. http://www. business.heacademy.ack.uk/resources/reflect/conf/2002/b amford

Lickerman, A. 2009. The effective Use of Silence. Psychology Today. http://www.psychologytoday.com/print/35809

Liu, J. 2001. Asian students' classroom communication patterns in U.S. universities: An emic perspective. Westport, CT: Ablex Publishing House.

Liu, N., \& W. Littlewood. 1997. Why do many students appear reluctant to participate in classroom learning discourse? System 25(3): 371-384.

Malley, M. P. 2005. Silence as a means of preserving the status quo: the case of ante-natal care in Ireland. Multilingua 24: 39-54.

Meyer, K. R. 2007, November. Student engagement in the classroom: An examination of student silence and participation. Paper presented at the meeting of the National Communication Association, Chicago, IL.

Meyer, K. R. 2009, November. Student classroom participation: Exploring student definitions of, motivations for, and recommendations regarding participation. Paper presented at the meeting of the National Communication Association, Chicago, IL.

Meyer, K. R., \& S. K. Hunt. 2004, April. Rethinking evaluation strategies for student participation. Paper presented at the meeting of the Central States Communication Association, Cleveland, $\mathrm{OH}$.

Nakane, I. 2005. Negotiating silence and speech in the classroom. Multilingиа 24: 75-100.

Ollin, R. 2008. Silent pedagogy and rethinking classroom practice: Structuring teaching through silence rather than talk. Cambridge Journal of Education 38(2): 265-280.

Petress, K. 2001. The ethics of student classroom silence. Journal of Instructional Psychology 28: 104-107.
Picard, M. 1952. The world of silence (S. Godman, Trans.). Chicago: Henry Regnery Company. (Original work published 1948).

Ping, W. 2010. A case study of an in-class silent postgraduate Chinese student in London Metropolitan University: A journey of learning. TESOL Journal 2: 207-214.

Plakans, B. K. 2011. Silence as a teaching tool. Yoga Journal. http://www. yogajournal.com/for_teachers/2433?print $=1$

Silence 2011. Oxford advanced learner's English dictionary. (A.S. Hornby, Ed.). Oxford. OUP, 1255.

Sivan, A., R. W. Leung, C. Woon, \& D. Kember. 2000. An implementation of active learning and its effect on the quality of student learning. Innovations in Education and Training International 37(4): 381-389.

Spizzica, M. 1997. Cultural differences within Western and Eastern education. In Academic communication across discipline and culture, ed. Z. Golebiowski \& H. Borland, 248-257. Melbourne: Victoria University of Technology.

Svinicki, M., \& W. J. McKeachie. 2011. McKeachie's teaching tips: Strategies, research, and theory for college and university teachers. 13th ed. Belmont, CA: Wadsworth.

Tannen, D. 1985. Silence: Anything but. In Perspectives on Silence, ed. D. Tannen, M. Saville-Troike, 93-111. Norwood, NJ: Ablex.

Tatar, S. 2005. Why keep silent? The classroom participation experiences of non-native-English-speaking students. Language and Intercultural Communication 5(3): 284-293.

Tatar, S. 2008. Classroom participation by international students: The case of Turkish graduate students. Journal of Studies in International Education 12: 204-221.

Wood, J. 1996. Should class participation be required in the basic communication course? Basic Communication Course Annual 8: 108-124.

Wu, X. 2009. The dynamics of Chinese face mechanisms and classroom behavior: A case study. Evaluation and Research in Education, 22(2): 87-105.

Xing, J., \& H. Spencer-Oatey. 2005. managing talk and non-talk in intercultural interactions: Insights from two Chinese-British business meetings. Multilingua 24: 55-74.

Zheng, X. 2010. Re-interpreting Silence: Chinese international students' verbal participation in U.S. universities. The International Journal of Learning 17(5): 451-464.

Zhou, Y. R., D. Knoke, \& I. Sakamoto. 2005. Rethinking silence in the classroom: Chinese students' experiences of sharing indigenous knowledge. International Journal of Inclusive Education 9(3): 287-311. 